\title{
The Veto on Images and the aniconic God in Ancient Israel
}

\author{
By TRYGGVE METTINGER
}

The prohibition of images in the decalogue appears to belong to Israel's differentia specifica. Already Tacitus observed: "Profana illis omnia, quae apud nos sacra." Israel's God is the aniconic God. The ban on images may be seen as a concrete expression of Israel's understanding of the deity. Our study is thus concerned with a key element in Israel's religion. But the nature of the material at our disposal makes an almost painful contrast to the importance and scope of our subject: it is not particularly plentiful, and some of the more important texts present problems for interpretation.

Throughout her long history Israel was quite familiar with the phenomenon of cultic images, a familiarity which she acquired by contact with other cultures. A pair of O.T. texts portray the actual manufacturing of images (Jer 10,1-9; Isa 44,9-20). Another text (Judg 17,4-5) has been interpreted as indicating what made up a complete image': the word pæsæl is taken to refer to the carved wooden image, whereas măssek $\bar{a}$ would represent the chased covering of precious metal (cf. Isa 30,22; 40,19², Jer 10,9). The term 'epôd is thought to refer to a cuirass-like case, and $t^{\prime}$ rapîm to a cultic mask (cf. Zech 10,2).

Biblical Hebrew has an extensive terminology for idols. Certain terms, like $t^{e} m \hat{u} n \bar{a}$ and $s æ m æ l$, are scarcely transparent; others are what linguists call semantically motivated. To illustrate from our modern languages: the German "Handschuh", but not the English "glove", is semantically motivated, it is self-explanatory". Several of the Hebrew terms for "idol" belong to this category. The word pæsæl normally denotes a hewn image, and is readily associated with the verb pasăl which is used, e.g., to describe how Moses cut the two stone tablets (Ex 34,1.4; Deut 10,1.3). Only in a few marginal cases is the word pæsæl used of a molten image (Isa 40,19;44,10; Jer 10,14$)$. The standard term for a "molten image" is măsseka a a word cognate with the verb nasăk, "pour out", which is also used for casting metal (Isa 40,$19 ; 44,10$ ). Similarly, the noun 'așab is related to a verb which bears the sense "form" in Job 10,8 .

These terms for "images", pæsæl, măssekā and 'aṣab, all lead to associa-

1 Alt apud Rad 1962, 229, n. 60.

2 On Isa 40,18-20 cf. Mettinger $77 \mathrm{ff}$.

${ }^{3}$ On semantic motivation $\mathrm{cf}$. Ullmann $83 \mathrm{ff}$.
On the group of words under discussion cf. Barr $17 \mathrm{ff}$. 
tions with the actual manufacturing process. 'așab has also been associated with the verb "aşăb II, "hurt", "grieve", having a strongly pejorative ring. This brings us to the group of markedly pejorative denotations for images. To this category belongs hæbæll/habalim, "vapour", "vanity", "idols". The word "wilitim is similar in meaning, indicating that the foreign idols are "things of nought". A nuance of strong physical repulsion lies in the word

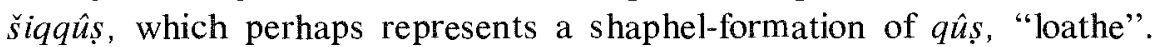
The same vowel pattern is found in gillulitm, a word which possibly can be related to *gel, "ball of dung". The word miplașæt may also be mentioned; though its concrete reference in the two texts in which it occurs (1 Kgs 15,13; 2 Chron 15,16) remains obscure, it conjures up associations with palăs, "shudder", and păllașît, "shuddering".

A large part of the terminology used to denote images is thus strongly negative in tone. The very choice of words seems to show a hostile attitude towards images on the part of the traditionists, with the result that our sources are governed by an anti-image tendentiousness. As always, our task must be to bring to the study of the sources an historical sensitivity and source-critical awareness. It is important to remember that an essential portion of the traditions of Israel's history have been transmitted to us by men for whom the first two commands of the decalogue-the prohibition of other gods and of images-made up the criteria for a theological criticism of Israel's past. I am here thinking of the material in the Deuteronomistic Historical Work (Deut-2 Kgs). The source-critical problem can be formulated as follows: Is this hostile attitude towards images characteristic of the transmitted material itself? Has the ban on images been inherited from the time of Moses, or is it the result of a later development?

One example will suffice to illustrate the nature of the problem. In Judg 8,22-28 we read how Gideon had an ephod made of precious metal and set up in his city of Ophrah.

And Gideon made an ephod of it and put it in his city, in Ophrah; and all Israel played the harlot $[$ zana $]$ after it there, and it became a snare to Gideon and to his family.

The use of zanā, "commit fornication", "play the harlot", to denote faithlessness towards JHWH probably originated with Hosea (cf. Hos 1,2; 4,12$15 ; 9,1)$. It is later found in Jeremiah $(2,20 ; 3,1.6 .8)$ and in Deuteronomistic literature (e.g. Ex 34,15; Deut 31,16; Judg 2,17). Viewed in this larger perspective, the latter part of the verse above quoted clearly represents a Deuteronomistic criticism of an undertaking the theological questionableness of which Gideon was apparently quite unaware.

\section{An Historical Outline}

We turn now to a study of the Israelite attitude towards images in its historical perspective in order to identify, if possible, the point at which the 
reaction against images began. In the accounts of the period in the wilderness, a couple of incidents are of interest for our subject ${ }^{4}$. Num 21,4-9 tells how Moses set up a bronze serpent on a pole. It is possible that this narrative is an etiology for a Canaanite cultic object which ended up in the temple in Jerusalem, but which here is legitimized by being associated with Moses $^{5}$. In any case, what is important for us is the fact that the Moses who in the decalogue forbids Israel to make any image of "anything that is in heaven above, or that is in the earth beneath, or that is in the water under the earth" (Ex 20,4) in Num 21 makes a bronze serpent and sets it up on a pole. The account in Numbers is free of any critical nuance. But the reaction came. In $2 \mathrm{Kgs} \mathrm{18,4}$ we are informed that king Hezekiah smashed the bronze serpent to pieces, "for until those days the people of Israel had burned incense to it".

The second narrative in the Pentateuch is the account in Ex 32 of how the Israelites under Aaron's leadership made a bull image of gold ${ }^{6}$. A number of points of contact with $1 \mathrm{Kgs} 12,25-32^{7}$ have led most scholars to view the chapter in its present complex form as representing a negative stance adopted towards the bull cult of king Jeroboam. Certain scholars find in this polemical situation the explanation for all parts of the narrative, and thus see the whole chapter as pure fiction. It would, however, be strange if circles hostile to Jeroboam in their polemic against him created a narrative which in point of fact accuses the entire nation of apostasy. In the end it is simpler to regard the narrative in Ex 32 as tied in one way or another to an actual event during the wilderness period.

The chapter is plagued by exegetical difficulties, and every analysis must be tentative in nature. Beyerlin has pointed out that the introductory section (v. 1-6) scarcely contains polemic against the image, but is rather neutral or even positive in its description. It is tempting to regard, with Beyerlin, these verses as the core of the tradition in this narrative ${ }^{8}$. Perhaps this original tradition functioned as an etiology for Jeroboam's bull cult in the tenth century, though this by no means excludes the possibility that the people actually made a bull image in the wilderness ${ }^{9}$. Certain difficulties in the narrative can be resolved if one sees here an expression of an early assimilation between JHWH and E1, who had the bull as his symbol (the bull image thus need not be associated with Baal). Evidence for such an early assimilation is found in Num 23,8.21-22 (cf. 24,8) ${ }^{10}$.

If the core of the tradition in Ex 32 is made up of a neutral or even positive account of how the people made a bull image in the wilderness, the

\footnotetext{
4 On Ex 17,8-16, a text that I shall not discuss here, cf. Eissfeldt $206 \mathrm{f}$.

5 Cf. Rowley $113 \mathrm{ff}$. esp. 137.

${ }^{6}$ For the literature on Ex $32 \mathrm{cf}$. Childs 553.

7 Cf. especially Aberbach $129 \mathrm{ff}$.
}

\footnotetext{
${ }^{8}$ Beyerlin $144 \mathrm{ff}$.

${ }^{9}$ Ib., 149, leaves open the question of what actually happened.

to On JHWH and El cf. especially Cross $1 \mathrm{ff}$; Vaux 456ff.
} 
later tradition branded their action a covenant violation (Ex 32, 15-20) ${ }^{11}$. When Moses comes down from the mountain, he smashes to pieces (sibber) the two tablets of the testimony, thus symbolically indicating that the people have broken the covenant with their bull image (cf. Akkad. tuppa heph as a symbolic action denoting the dissolving of a contract/treaty ${ }^{12}$ ). Moses proceeds to destroy the bull image: he burns it, grinds it to powder and scatters it on the water, which he makes the people drink (v. 20). This procedure has been interpreted in widely different ways ${ }^{13}$. It is difficult to escape the conclusion that the account contains among other things an allusion to the ordeal which a woman suspected of adultery had to go through (Num 5,11-31). If so, the later tradition in Ex 32 is in line with Hosea's use of the verb zanā " commit fornication", "play the harlot"14.

From the Pentateuch's traditions about the bronze serpent and Aaron's bull we turn to the material in the book of Judges. When Gideon made his ephod (Judg 8,27), he was certainly unaware that this would one day be regarded as a questionable undertaking. The denunciation contained in the narrative is to be attributed to the Deuteronomists' iconoclastic ideal. A detailed depiction of the making of an image and its later fate can be read in Judg 17-18. The Ephraimite Micah used silver which his mother had dedicated to JHWH in order to make a pæsæl ûmăsseka $\bar{a}$. This image was then placed in a shrine which he also equipped with an 'epôd and $t^{e}$ rapîm $(17,1-5)$. A Levite from Judah was appointed priest (17,7-13). Both the priest and the cultic equipment were, however, taken as plunder by the Danites, and thus ended up in the town of Dan. We need not here go into the question how this narrative is related to the tradition about Jeroboam's cult at the same place ${ }^{15}$. What is of importance for our subject is the fact that an Israelite tribe during the period when the land was settled had in its sanctuary a cultic object which in all likelihood was an image of JHWH. Over Micah, who made the image, his mother pronounced the following words: "Blessed be my son by the LORD" $(17,2)$; and the image was made of silver which had been dedicated "to the LORD" $(17,3)$.

We pass on now to the period of the kingdoms and thus to the question of the attitude of the Israelite state religion towards images. According to $1 \mathrm{Kgs} 12,25-32$, the first ruler of the Northern Kingdom, Jeroboam I, had two bull images made and set up in Bethel and Dan. This account is clearly pro-Judaean in character and expresses a pointed criticism of Jeroboam's cultic installations. This critical tendentiousness presumably lies behind the plural form used in the presentation formula, "Behold your gods, O Israel,

11 Cf. Beyerlin $149 \mathrm{ff}$.

${ }^{12}$ For references see Akkadisches, $340 \mathrm{f}$.

${ }^{13}$ Dussaud, 245, points to the burning of the sin offering. Loewenstamm, $483 \mathrm{ff}$, draws attention to the treatment of Mot in Ugarit (CF. Gordon 49 2, 30 ff).
14 Cf. above.

$15 \mathrm{Cf}$. Noth $133 \mathrm{ff}$. On Judg 17-21 as part of the Deuteronomistic Historical Work cf. Veijola $15 \mathrm{ff}$. 
who brought you up out of the land of Egypt!" so that this plural, which is to be understood as numeric ${ }^{16}$ (and not as an abstract plural) expresses a charge of polytheism ${ }^{17}$. According to the text, Jeroboam set up two images, one in Bethel and one in Dan. Recently, however, Motzki has provided an interesting argument for the theory that Jeroboam in fact made only a single image which was set up in Bethel; the reference in the rext to a counterpart in Dan would then be a fiction intended to prepare the way for the pejorative plural of the presentation formula. Motzki bases his argument on texts which speak of a cultic image in the singular (e.g. Hos 10,5 , emended text; $8,4-6 ; 2 \mathrm{Kgs} 17,16$ ) and on the fact that Hosea and Amos (with the exception of Am 8,14) are silent about Dan ${ }^{18}$. The plural used in the tradition about Jeroboam's cultic bulls has then penetrated the formula in the tradition about Aaron's bull (Ex 32,4.8 cf. v.1), where in fact it does not fit the account of Aaron's single bull image.

Thus we have at least in Bethel a cult associated with an image in the form of a bull or a bull calf. The cultic symbols in question is scarcely to be taken as evidencing a Baal-syncretistic worship of JHWH; rather it represents an older assimilation between $\mathrm{JHWH}_{\mathrm{H}}$ and $\mathrm{El}^{19}$. In the Ugaritic texts we find several times $t r$ or $\underline{t} w r$, "bull", as an epitheton ornans for El. In the O.T. the assimilation JHWH-El is early attested in the Balaam oracles:

How can I curse whom El has not cursed?

How can I denounce whome JHWH has not denounced? (Num 23,8)

JHWH, his God, is with him ...

El brought him [see app.!] out of Egypt,

he is like the wild ox's horns to him. (Num 23,21-22; cf. 24,8)

El, who is here compared with the wild ox (NB El as bull in Ugarit), is in this text associated with the exodus from Egypt, as is later Jeroboam's bull image in Bethel. That the place in which Jeroboam set up his image bears the name Beth-El, "El's house", is not without interest in this context. The clan of Jacob had of course close connections with Bethel (Gen $28,10-22 ; 31,13 ; 35,7)$. With this in mind, it is interesting to note that we meet the phrase 'a $b \hat{i}$ j $\breve{a}^{c a} q o b$ as a name for the God worshipped by Jacob (Gen 49,24) - a name which certain scholars translate "Jacob's bull"'20. Since Baal mythology otherwise plays no role in the patriarchal narratives, a possible Canaanite background should be sought in the El traditions.

These indications-they are no more than indications-lend support to two suppositions:

16 Cf. Donner 47.

17 Cf. Weippert 104.

$18 \mathrm{Cf}$. Motzki $470 \mathrm{ff}$.

$19 \mathrm{Cf}$, above no. 10 .

20 For a discussion cf. Kapelrud $43 \mathrm{ff}$. The cases where it appears as a divine designation and without a dagesh are: Gen 49,24; Ps 132,2.5; Isa 49,26 and 60,16; cf. Isa 1,24. Note also the personal name ${ }^{c} g l j w$ in the Samaria Ostraca no. 41; cf. Reisner 236. 
(a) The bull cult in Bethel had ancient roots from a time long before Jeroboam;

(b) The bull symbol set up by Jeroboam was primarily related not to JHWHBaal, but to JHWH-El.

Further support for this line of thinking would be found in Hos 8,6 if, for the M.T.'s kî mijjiśra'el, we adopted the proposed emendation, kî $m \hat{\imath}$ šor "el, "for who is the bull El"; but it is not to be denied that the transmitted text appears to provide at least as good sense in the context ${ }^{21}$.

What, then, was the relation between the bull image and the deity with which it was associated? Was the cultic object a direct symbol for the deity? Or how are we to conceive the matter? Hosea's polemical cry, "A god he is not!" (Hos 8,6) suggests that the image at his time was regarded as a symbol for the deity. The conception then current was apparently that the deity was represented in the bull image ${ }^{22}$. It is, however, not for that reason certain that Jeroboam $\mathbb{I}$ and his contemporaries more than one and a half centuries earlier understood the image in this way.

When Jeroboam's bull image is seen in a larger ideo-historical context, a new perspective becomes apparent. The purpose of Jeroboam's cultic program is said to be to put a stop to his people's pilgrimages to the central sanctuary of the Southern Kingdom. "You have gone up to Jerusalem long enough," the text has him say $(1 \mathrm{Kgs} 12,28)$. Undoubtedly the Judaean traditionists here give expression to the Deuteronomistic principle of recognizing only the JHWH-cult observed in Jerusalem. But this is not the whole truth ${ }^{23}$. With the historical situation at the time of Jeroboam's new regime in view, it is a highly plausible supposition that his cultic politics were formed in deliberate competition with Jerusalem, and that his intention was to provide a convincing alternative to the Solomonic temple in Jerusalem for the pious people of his realm ${ }^{24}$.

The cultic legitimacy of Jerusalem was the result of David's transfer of the ark to that city (2 Sam 6). The ark was, of course, the most important cultic object from the pre-monarchic period ${ }^{25}$. Even before the period of the kingdoms, a theology of divine presence was connected with the ark. As often as the ark was taken up, Moses said, "Arise, O LORD," and when it was placed down he said, "Return, O LORD" (Num 10,35-36). The same idea is attested in 1 Sam 4,6-7: the Philistines, on learning that the ark had come into the Israelite camp, said, "A god has come into the camp." In both these texts, language is used which stresses the close connection between JHWH and the ark, while at the same time the conceptual distinction between the god and his cultic symbol is maintained.

In time, the ark found a place in a temple in Palestine, in Shiloh and

${ }^{21}$ Cf. Wolff 182.
${ }^{22}$ Cf. ib. 181.
${ }^{23}$ Contra Debus $35 \mathrm{ff}$.
${ }^{24}$ Cf. especially Zimmerli 1974, $248 \mathrm{ff}$.

${ }^{25}$ For a survey of the research on the ark ef. Schmitt $13 \mathrm{ff}$. 
later in Jerusalem. Already in Shiloh we encounter the tradition of the ark's connection with the cherubim: the ark is here associated with the divine designation, "the LORD of hosts, who is enthroned on the cherubim" (1 Sam 4,4 cf. 2 Sam 6,2) ${ }^{26}$. In the Jerusalem temple the ark is similarly linked with the cherubim. When it is brought into Solomon's temple, it is placed "underneath the wings of the cherubim" (1 Kgs 8,6). These cherubim were part of a contrivance which is described in more detail in $1 \mathrm{Kgs}$ $6,23-27$, and which has been illuminated in an interesting way by the iconic art of the ancient Near East ${ }^{27}$. Solomon's cherubim were 10 cubits, or nearly 4.5 metres, high. The cherubim of the Priestly tradition's Tent of Meeting faced each other (Ex 25,20); by way of contrast, those of Solomon's temple stood parallel to each other. Each cherub touched with its outer wing one of the building's walls. The inner wing of each touched that of the other in the middle of the building. M. Haran is probably correct in thinking that this pair of inner wings constituted JHWH's throne ${ }^{28}$. This interpretation is supported by Ezek 10,1, which shows that the cherubim were part of a throne contrivance (cf. also Ezek 1,22-26). The ark, which was only $1 \frac{1}{2}$ cubits in height (cf. Ex 25,10), made up the footstool (Ps 99,5; 132,7; 1 Chron 28,2). JHWH was thought to sit unseen in royal majesty over the cherub throne and the ark. The divine epithet, "he who is enthroned on the cherubim," is to be understood from this background. It is against this background as well that we are to understand the statements that the ark's role as throne and footstool has been taken over by Zion and Jerusalem (Jer 3,16-17; Lam 2, 1; cf. also Ezek 43,7).

If Jeroboam's intention was to provide an alternative to the most important cultic object of the Southern Kingdom, then the bull image (or images?) ought to be seen as analogous to the empty cherub throne in the Jerusalem temple. The comparative material from the iconic art of the ancient Near East provides further support for this understanding. As Obbink has observed, there are examples where the deity is represented as standing on the back of a bull ${ }^{29}$. The male figure above the bull then symbolizes the god. But the animal itself is only the god's pedestal or socle animal. Similarly, Jeroboam's bull image is thus only the visible pedestal over which JHWH stands unseen. We are confronted by the Northern Kingdom's counterpart to the empty divine throne in the Holy of Holies of the Jerusalem temple. In spite of Eissfeldt's attempt to introduce another interpretation $^{30}$, the view above outlined has quite rightly won general ac-

${ }^{26}$ The same designation of God, jôšeb $h a ̆ k k^{e} r u b i ̂ m$, is also found in $2 \mathrm{Kgs} \mathrm{19,15}$; Isa 37,$16 ;$ PS 80,$2 ; 99,1 ; 1$ Chron 13,6. Cf. also 2 Sam 22,11 and $P$ s 18,11.

27 For an excellent discussion cf. Keel 1977 , $15 \mathrm{ff}$.
${ }^{28}$ Cf. Haran, $30 \mathrm{ff}$., $89 \mathrm{ff}$., esp. $35 \mathrm{f}$.

${ }^{29}$ Obbink $268 \mathrm{f}$. For illustrations cf. Welten 102, Keel 1977, Abb. $97 \mathrm{ff}$. and cf. no $109 \mathrm{ff}$. 30 Eissfeldt, $190 \mathrm{ff}$., holds that we have to do with a cultic standard, crowned by a bull image, in Ex 32 and $1 \mathrm{Kgs} 12$. 
ceptance among scholars ${ }^{31}$. We must therefore avoid concluding too much from the "presentation formula" with which Jeroboam introduces his cultic object: "Behold your God, O Israel, who brought you up out of the land of Egypt" (1 Kgs 12,28) $)^{32}$. We have every reason to reckon with an original distinction between socle animal and the unseen deity above it.

If it is correct to draw an analogy between the cherub throne with the ark in the temple in Jerusalem and Jeroboam's bull (or bulls), the question arises how the former cultic symbol escaped the theological censure to which the latter was obviously subjected ${ }^{33}$. Various factors might be mentioned. The fact that the former cultic symbol was hidden in the Holy of Holies protected it against the false interpretations inevitable in a degenerate popular cult. Its very form-a cherub throne with the ark-did not invite the same Baalistic misunderstandings as a bull image; for the bull was not only El's, but also Baal's animal. Moreover, we may suppose that the notion of a throne in Jerusalem was for a long period sufficiently alive to guarantee that the cultic symbol as such was not confused with the unseen deity who sat above it. Just the same, the ark-theology could not in the end remain uninfluenced by the spreading iconoclastic tendencies associated with Hosea and the Deuteronomistic movement. G. von Rad has shown in a classic article how the ark in the Deuteronomistic theology lost its traditional character of a numinous symbol for God's presence and, via a process of rationalization was reduced to a mere container for the tablets of the Law (Deut 10,1-5; $1 \mathrm{Kgs} 8,9)^{34}$.

\section{When were Images Prohibited?}

When then was the prohibition of images which we meet in the decalogue formulated?

The classical ark-theology has its centre in the notion of the aniconic God. The throne is empty: the place of the image is occupied by the unseen God. The official Jerusalem cult was imageless in the sense that it lacked a direct symbol for JHWH. The cherub throne with the ark can not be regarded as such a symbol. Nor can Nehushtan ( $2 \mathrm{Kgs} 18,4)$. The absence of images is here early a fact. Our question, however, is when this absence took programmatic form as a prohibition of images. Often a dogma is first formulated as an answer to a crisis. Might this perhaps be the case here as well?

The answer to our question must do justice to two factors. On the one hand, we find that a man like Jehu, who in his zeal for JHWH had Baal's temple in Samaria destroyed ( $2 \mathrm{Kgs} 10,18-28$ ), took no action against Jeroboam's bull cult:

${ }^{31}$ Cf. Weippert 103, n. 55 (lit.).

32 Jeroboam himself certainly used the singular.
${ }^{33}$ For the following ef. Zimmerli 1974, $258 \mathrm{f}$.

${ }^{34}$ Cf. $\operatorname{Rad} 1961,109 \mathrm{ff}$. 
But Jehu did not turn aside from the sins of Jeroboam the son of Nebat, which he made Israel to sin, the golden calves that were in Bethel, and in Dan. (2 Kgs 10,29)

Jehu's position was thus characterized by activity against Baal syncretism, but neutrality towards the bull cult. The same position was apparently that of Elijah and Elisha. Nor does Amos, who was active in Bethel where Jeroboam had set up his bull image, seem to have reacted against it. Even if Am 5,26 is authentic-and this is disputed-a genuine Israelite cult symbol is not the issue; besides, it contains a key term for an image, sælæm, which does not appear in the texts prohibiting images ${ }^{35}$.

On the other hand, in the richly developed metaphorical language used by the prophets to describe JHWH, there is a striking reserve towards the use of the bull as a metaphor for $\mathrm{JHWH}^{36}$. And above all: the formula "the sins of Jeroboam the son of Nebat" is used time and time again by the Deuteronomists to brand the cultic symbol of Jeroboam with their condemnation $^{37}$. Behind this polemic in the Deuteronomistic Historical Work seems to lie the formulated prohibition of images. Compare the formulation: "And they forsook all the commandments of the LORD their God, and made for themselves molten images [măssekā, sing.!] of two calves ...' ( $2 \mathrm{Kgs} 17,16$; cf. Ex 34,17). It may be added in parenthesis that we are not here dealing with an isolated phenomenon. The Deuteronomistic censure not only turned against artistically created symbols, but even against more "formless" cultic objects such as the originally legitimate masseboth ${ }^{38}$. And we have already seen how the new theological signals influenced the classical ark-theology.

That Hosea played a very significant role in the development of an iconoclastic theology is clearly shown by the sources ${ }^{39}$. This prophet gives expression to a clear and conscious criticism of "Samaria's calf" (Hos 8,5 ), by which the prophet means the cultic symbol which Jeroboam I had erected in the national sanctuary in Bethel (cf. Hos 10,5) ${ }^{40}$. Two things deserve special attention. First, the original distinction between JHWH and the bull seems to have become increasingly blurred in the popular consciousness. Hosea's declaration, "A god he is not!" (Hos 8,6) is directed against just such a confusion of the pedestal animal and the deity. Second, though originally related to JHWH-El, the bull image had in the course of time become associated with Baal. Hosea's struggle was in fact a fullscale attack on the Baalization of JHWH. His struggle against Baal becomes eo ipso a struggle against the bull image in Bethel.

35 For a discussion of the syntax in Am $5,25-27 \mathrm{cf}$. Erlandsson $76 \mathrm{ff}$.

${ }^{36}$ Cf. Hempel 1924, 74 ff., esp. $100 \mathrm{f}$.

${ }^{37}$ On this formula cf. Debus, esp. $93 \mathrm{ff}$.

${ }^{38}$ Compare Gen $28,18.22 ; 31,13 ; 35,14$; Ex
24,4; Isa 19,19 f. with Deut 16,22 and Lev 26,1 .

${ }^{39}$ Cf. Hos 3,$4 ; 4,17 ; 8,1-7 ; 10,1-8 ; 10,10$; 13,$2 ; 14,9$.

${ }^{40} \mathrm{Cf}$. the discussion in Wolff $179 \mathrm{f}$. 
From Hosea the line can be traced to Deuteronomy and Josiah's iconoclastic reform. It is a well-known fact that there are numerous connections between Hosea and Deuteronomy, connections which lead us to assume an influx of northern traditions into Judah after the fall of Samaria in $722 / 721$ B.C. ${ }^{41}$. One of these points of contact is the plemic against images to be found in both Hosea and Deuteronomy. In both writings we find the image described as the work of craftsmen (mă ${ }^{c} a \hat{s} e$ harašîm: Hos 13,2; Deut 27,15). In both, images are described as man-made gods ( $m \breve{a}^{\mathrm{c} a} \hat{s} \hat{e}$ $j^{e} d \hat{e}$ 'adam: Hos 14,4 ; Deut 4,$\left.28 ; 31,29\right)^{42}$; the same statement is attested in Isa 2,8 and Mic 5,12, i.e. from the period between Hosea and Deuteronomy.

The actual polemic against images can thus be traced back to Hosea in the eighth century, though scarcely earlier. To judge by the evidence, it began with this prophet, received its peripeteia in Deuteronomy and the Deuteronomistic Historical Work, and its finale in Deutero-Isaiah (e.g. Isa $40,18-20 ; 41,6 \mathrm{f} . ; 44,9-20)^{43}$.

We may here pause and summarize before proceeding further. From the pre-monarchic period we have the traditions-which in all probability were originally neutral-about the bronze serpent and Aaron's bull; the polemic in the latter narrative appears not to be original. We may here include the stories of Gideon's ephod and Micah's image as well. The official Jerusalem cult was undoubtedly aniconic, but the absence of images had scarcely taken on the character of a command in a fixed prohibition. The ark had not yet been rationalized into a mere container for the tablets of the testimony. In the Northern Kingdom the bull image in Bethel (and in Dan?) escaped prophetic criticism for one and a half centuries. Jehu's reforms did not alter this fact, nor do Elijah and Elisha seem to have expressed misgivings. First in the eighth century the prophetic polemic against images is formulated by Hosea immediately in its full force.

What conclusions may we draw about the dating of the prohibition of images? In my view there exist two primary possibilities: (a) If the prohibition came early and goes back to the wilderness period, then for reasons unknown to us it long lay inactive, only to be revived by Hosea. (b) The second alternative is that Moses never took a position on the question of images, that the prohibition is rather the product of prophetic polemic against them. If so, the prophets have here preceded the Law. The fact that Hosea makes no reference to a prohibition inherited from the time of Moses-which would have given his iconoclastic declarations a

${ }^{41} \mathrm{Cf}$. especially Alt $250 \mathrm{ff}$.; Weinfeld $366 \mathrm{ff}$.

${ }^{42} \mathrm{Cf}$. also some other passages in the Deuteronomistic literature: $1 \mathrm{Kgs} 16,7 ; 2 \mathrm{Kgs}$ 19,$18 ; 22,17 ;$ Jer 1,$16 ; 25,6-7 ; 32,30 ; 44,8$.

Note also Ps 115,$4 ; 135,15$.
${ }^{43}$ On these passages cf. Preuss $192 \mathrm{ff}$. On the polemic against images $\mathrm{cf}$. also Rad 1970, $229 \mathrm{ff}$. 
special weight-means that the second alternative (b) must be regarded as the simplest explanation of the available material ${ }^{44}$.

The prohibition has been transmitted in a variety of forms ( $\operatorname{Ex} 20,3-6$; Deut 5,7-10; Ex 20,22-23; 34,17; Lev 19,4; 26,1; Deut 27,15). Which form is the oldest? In perfect agreement with the observations made above, we may suppose that the oldest form of the command is the one which is directed against molten images of silver or gold (măssekā), or more precisely, against the bull images; this is found in Ex 34,17: "You shall make for yourself no molten gods ("⿱⺈ lohê măssekā)." ${ }_{45}$

The later, classical form of the command in the decalogue (Ex 20,3-6; Deut 5,7-10), is, as Zimmerli has shown, a complex one ${ }^{46}$. In Ex 20, v. 5-6 are an interpretative addition. This is apparent from the fact that the plural suffixes in v. 5 ("you shall not bow down to them or serve them...") do not refer back to the (singular) image in v. 4 but rather to the other gods in v. 3. Furthermore, the expression "bow down and worship" in v. 5 was never used with an image as object, but is rather a Deuteronomistic expression for an illegitimate relation to strange gods. The core of the prohibition in $\mathrm{Ex} 20$ is found in v. 4a: lo" tă as $\not l^{e} k a$ pæsæl, "you shall not make for yourself a graven image". The addition of $v .5-6$ has placed the prohibition under the shadow of the first command-quite in agreement with the intentions behind the prophetic polemic against images as it is found, for example, in Hosea. Ex $20,4 \mathrm{~b}$ is, according to Zimmerli, a still later addition.

\section{Theological Motifs}

We have now discussed the origin and different forms of the prohibition of images. What remains is undeniably the most difficult question in this context, but just as undeniably one of the most interesting: what ideological motifs are connected with the prohibition of images ${ }^{47}$ ? We have already touched on this question with the observation that the historical force behind the "dogmatization" which banned images is to be found in the prophetic struggle against the Baalization of JHWH. The prohibition is thus one expression of the reaction against Canaanite culture and religion which found its most extreme form in the Rechabites' stubborn fight for nomadic ideals and their consequent refusal to live in houses, take up agriculture, or drink wine (Jer $35,6-7)$. When the prohibition is seen in this perspective, the question becomes little more than academic whether the ban was di-

\footnotetext{
44 A question that needs to be discussed anew is the date of the first commandment, cf. Golka $352 \mathrm{ff}$.

${ }^{45} \mathrm{Cf}$. Mowinckel $264 \mathrm{f}$. Note that măsseka is used to denote a bull image in $\operatorname{Ex~} 32,4.8$; Hos 13,2; Deut 9,16; Ps 106,19f.; 2 Kgs 17,16 .
}

46 Cf. Zimmerli 1969, 234 ff. For the later discussion cf. Halbe 123, n. 73 (lit.).

${ }^{47}$ A broad treatment is found in Bernhardt $69 \mathrm{ff}$. Cf. also Keel 1977, $37 \mathrm{ff}$. 
rected against images of foreign gods or representations of Israel's God. It is directed against both, the intention being to prohibit all cultic images. Its place in the decalogue is thus quite appropriate: it forms the transition from the prohibition of other gods to the commands regarding the divine name and the sabbath, both of which refer to the JHWH cult.

Our question can, however, be put at a deeper level. The prohibition is of course not to be understood in an exclusively negative sense, as a safeguard against syncretism. It may also be understood as positively expressing the distinctive character of Israel's understanding of the deity.

Attempts to thus penetrate to the ideological roots of the prohibition of images have at times pointed to the refusal of Israel's God to allow himself to be manipulated by magical means, to his Unverfügbarkeit ${ }^{48}$. An image mediates revelation. The static presence in an image, an object charged with power at human disposal, was for Israelite religion something foreign. The prohibition of images would thus be parallel in effect to the third commandment, which was intended to protect the divine name from magical misuse. But this interpretation of the prohibition is debatable ${ }^{49}$. If JHWH's Unverfügbarkeit played such a role, Israel's God would never even have revealed his name. The magic of the Near East shows us that the name even more than a representation placed the being in question at human disposal. A general reference to the well-known Egyptian execration texts, directed against foreign princes, will here suffice. But that is not all. The notion of JHWH's Unverfügbarkeit scarcely suits what the texts themselves imply about God's active presence in such cultic objects as the ark (cf. 1 Sam 4,4-9).

Comparison with the third commandment is thus not particularly enlightening. Still, the texts themselves-admittedly in a pair of quite late references-provide direct indications of great interest for our purposes. One such text is Ex $20,4 \mathrm{~b}$. Here Israel is forbidden to make any image "of anything that is in heaven above, or that is in the earth beneath, or that is in the water under the earth". This statement gives the prohibition its maximal scope, since the triple division describes the world in its entirety. While the religions of Israel's neighbours had gods in heaven, on earth, and in the underworld with their respective images, for Israel not only the earth but also heaven is incapable of offering anything to be compared with God. Here we approach what is perhaps the deepest motif in the prohibition of images: to safeguard the border between God and the world, to accentuate his transcendence.

The other text is Deut 4,9-20, which contains an extended interpretation of the prohibition. The command here finds its motivation in JHWH's method of revealing himself on Horeb: "Then the LORD spoke to you out

${ }^{48} \mathrm{Cf}$. for instance Zimmerli $1969,245 \mathrm{f}$;

${ }^{49}$ As was pointed out by Keel 1977, 37 .

$\operatorname{Rad} 1962,230$. 
of the midst of the fire; you heard the sound of words, but saw no form; there was only a voice" (v. 12; cf. v. 15 and Ex 20,22-23). Other nations resort to images for their contact with the deity; Israel is pointed to God's word. To this motivation based on the Sinai theophany, however, another is implicitly added in v. 16-18. Here Israel is admonished not to make any image, "the likeness of male or female, the likeness of any beast that is on the earth, the likeness of any winged bird that flies in the air, the likeness of anything that creeps on the ground, the likeness of any fish that is in the water under the earth". One can scarcely escape the impression that we are here confronted with the same vocabulary as in the Priestly account of the creation in Gen 1 (zakar $\hat{u} n^{e} q e b \bar{a}, b^{e} h e m \bar{a}$, ræmæs). This text, too, understands the prohibition of images as an expression of the Creator's transcendence over what he has created ${ }^{50}$.

Our journey through the O.T. texts has reached its end. As a souvenir we may take with us the insight that the prohibition of images was probably formulated quite late, but that the official cult was early aniconic: over the cherub throne and the ark, the God of Israel was enthroned in unseen majesty. The place usually occupied by the image is empty. There is thus in Israelite religion a vacuum, a vacuum which tends to be filled. The roles played by the word of God, the name of God, and man as the image of God in the O.T. should be studied in this larger perspective as functions in a structure of which the notion of the aniconic god is the very centre ${ }^{51}$.

Translated by Stephen Westerholm.

\section{Bibliography}

FRLANT Forschungen zur Religion und Literatur des Aiten und Neuen Testaments

ThB Theologische Bücherei

VT Vetus Testamentum

VT Suppl Vetus Testamentum. Supplementum

ZAW Zeitschrift für die alttestamentliche Wissenschaft

ZAWBeih Zeitschrift für die alttestamentliche Wissenschaft. Beiheft

ZDPV Zeitschrift des Deutschen Palästina-Vereins

Aberbach, M., Smolar, L., 1967, Aaron, Jeroboam, and the golden calves. Journal of Biblical literature 86.

Ahlström, G., 1970s, An Israelite god figurine from Hazor. Orientalia Suecana 19-20.

- 1975, An Israelite god figurine, once more. VT 25.

${ }^{50}$ Cf. Rad 1964, 61 f.; Schmidt 1968, 82; 1973, $25 \mathrm{ff}$.

${ }^{51}$ For further observations on the problems discussed in this paper cf. Ahlström 1970s, $54 \mathrm{ff} . ; 1975,106 \mathrm{ff}$., Blais $1 \mathrm{ff}$.; Carroll $51 \mathrm{ff}$;
Dus $268 \mathrm{ff} . ;$ Gutmann $161 \mathrm{ff}$; Hempel $1 \mathrm{ff}$; Kruyswijk $1 \mathrm{ff}$; North $151 \mathrm{ff}$; Ouellette 504 ff.; Schrade 1 ff.; Soggin 179 ff.; Vischer $764 \mathrm{ff}$. 
Akkadisches 1965, Akkadisches Handwörterbuch 1. [Hrsg.] von W. von Soden. Wiesbaden.

Alt, A. 1964, Die Heimat des Deuteronomiums. Alt, A., Kleine Schriften 2. München.

Barr, J., 1968, The image of God in the Book of Genesis-a study of terminology. Bulletin of John Ryland's library 51.

Bernhardt, K.-H., 1956, Gott und Bild. Theologische Arbeiten 2. Berlin.

Beyerlin, W., 1961, Herkunft und Geschichte der ältesten Sinaitraditionen. Tübingen.

Blais, G., 1971. Interdit des images dans l'Ancien Testament. "Lizentiatsarbeit" Fribourg (vide Elenchus 54/1973, 331).

Carroll, R., 1977, The aniconic god and the cult of images. Studia Theologica 31.

Childs, B., 1974, Exodus. A commentary. London.

Cross, F., 1973, Canaanite myth and Hebrew epic. Cambridge, Mass.

Debus, J., 1967, Die Sünde Jerobeams. FRLANT 93. Göttingen.

Donner, H., 1973, "Hier sind deine Götter, Israel!' Wort und Geschichte. Festschrift Karl Elliger. Alter Orient und Altes Testament 18. Ed. H. Gese und H. Rüger. Neukirchen.

Dus, J., 1965, Ein richterliches Stierbildheiligtum zu Bethel. ZAW 77.

Dussaud, R., 1921, Les origines cananéennes du sacrifice israélite. Paris.

Eissfeldt, O., 1940s, Lade und Stierbild. ZAW 58.

Erlandsson, S., 1968, Amos 5:25-27, ett crux interpretum. Svensk exegetisk årsbok 33.

Golka, F., 1978, Schwierigkeiten bei der Datierung des Fremdgötterverbotes. VT 28. Gordon, C., 1965, Ugaritic textbook. Analecta Orientalia 38. Roma.

Gutmann, J., 1961, The "second commandment" and the image in Judaism. Hebrew Union College annual 32.

Halbe, J., 1975, Das Privilgerecht Jahwes. Ex 34,10-26. FRLANT 114. Göttingen.

Haran, M., 1959, The ark and the cherubim. Israel exploration journal 9.

Hempel, J., 1924, Jahwegleichnisse der israelitischen Propheten. ZAW 42.

- 1957, Das Bild in Bibel und Gottesdienst. Sammlung gemeinverständlicher Vorträge 212. Tübingen.

Kapelrud, A., 1973, 'abîrp ăbbîr. Theologisches Wörterbuch zum Alten Testament 1. Ed. G. Botterweck and H. Ringgren. Stuttgart.

Keel, O., 1973, Das Vergraben der "fremden Götter" in Genesis xxxv 4b. VT 23.

- 1977, Jahwe-Visionen und Siegelkunst. Stuttgarter Bibelstudien $84 \mathrm{f}$. Stuttgart.

Kruyswijk, A., 1962, "Geen gesneden beeld ...". Diss. Amsterdam.

Loewenstamm, S., 1967, The making and the destruction of the golden calf. Biblica 48.

Mettinger, T., 1974, The elimination of a crux? VTSuppl 26.

Motzki, H., 1975, Ein Beitrag zum Problem des Stierkultes in der Religionsgeschichte Israels. VT 25.

Mowinckel, S., 1930, Wann wurde der Jahwäkultus in Jerusalem offiziell bildlos. Acta Orientalia 8.

North, C., 1958, The essence of idolatry. Von Ugarit nach Qumran. Festschrift O. Eissfeldt. ZAWBeih 77. Ed. J. Hempel. Berlin.

Noth, M., 1971, Der Hintergrund von Richter 17-18. Noth, M., Aufsätze zur biblischen Landes- und Altertumskunde 1. Ed. H. Wolff. Neukirchen.

Obbink, H., 1929, Jahwebilder. ZAW 47.

Ouellette, J., 1967, Le deuxième commendement et le rôle de l'image dans la symbolique religieuse de l'Ancien Testament. Revue Biblioque 74.

Preuss, H., 1971, Verspottung fremder Religionen im Alten Testament. Beiträge zur Wissenschaft vom Alten und Neuen Testament 92. Stuttgart. 
Rad, G. von, 1961, Zelt und Lade. Rad, G., Gesammelte Studien zum Alten Testament. ThB 8. München.

- 1962, Theologie des Alten Testaments 2. München.

- 1964, Aspekte alttestamentlichen Weltverständnisses. Evangelische Theologie 24.

- 1970, Weisheit in Israel. Neukirchen.

Reisner, G., Fisher, C., Lyon, D. 1924, Harvard excavations at Samaria 19081910, 1. Cambridge, Mass.

Rowley, H., 1939, Zadok and Nehushtan. Journal of Biblical literature 58.

Schmidt, W. 1968, Alttestamentlicher Glaube und seine Umwelt. Neukirchen.

- 1973, Ausprägungen des Bilderverbots? Das Wort und die Wörter. Festschrift G. Friedrich. Ed. H. Balz, S. Schulz. Stuttgart.

Schmitt, R., 1972, Zelt und Lade als Thema alttestamentlicher Wissenschaft. Gütersloh.

Schrade, H., 1949, Der verborgene Gott. Gottesbild und Gottesvorstellung in Israel und im Alten Orient. Stuttgart.

Soggin, J., 1966, Der offiziell geförderte Synkretismus in Israel während des 10. Jahrhunderts. ZAW 78.

Ullmann, S., 1967, The principles of semantics. Oxford.

Vaux, R. de, 1978, The early history of Israel 1. London.

Veijola, T., 1977, Das Königtum in der Beurteilung der deuteronomistischen Historiographie. Annales Academiae Scientiarum Fennicae B 198. Helsinki.

Vischer, W., 1956, Du sollst dir kein Bildnis machen. Antwort. Festschrift Karl Barth. Zollikon.

Weinfeld, M., 1972, Deuteronomy and the Deuteronomic school. Oxford.

Weippert, M., 1961, Gott und Stier. ZDPV 77.

Welten, P., 1977, Götterbild, männliches. Biblisches Reallexikon. Ed. K. Galling. Tübingen.

Wolff, H., 1965. Dodekapropheton 1. Hosea. Biblischer Kommentar 14,1. Neukirchen.

Zimmerli, W., 1969, Das zweite Gebot. Zimmerli, W., Gottes Offenbarung. ThB 19.

- 1974, Das Bilderverbot in der Geschichte des alten Israel (Goldenes Kalb, Eherne Schlange, Mazzeben und Lade). Zimmerli, W., Studien zur alttestamentlichen Theologie und Prophetie 2. ThB 51. 